\title{
Mortality from asthma and chronic obstructive pulmonary disease among workers in a soft paper mill: a case-referent study
}

\author{
K THORÉN,' B JÄRVHOLM,' U MORGAN ${ }^{2}$
}

From the Department of Occupational Medicine, ${ }^{1}$ Sahlgren Hospital, S-412 66 Göteborg, and Industrial Health Care Unit, ${ }^{2}$ Edet AB, S-463 00 Lilla Edet, Sweden

ABSTRACT In a case-referent study encompassing 33 cases and 228 referents the potential risk for $\stackrel{\vec{\circ}}{\circ}$ asthma and chronic obstructive pulmonary disease and respiratory cancer among workers in a soft ${ }_{\overrightarrow{0}}^{\omega}$ paper mill was evaluated. The cases were selected from registers of deaths and burials in the parishes 0 around the paper mill. Information on exposure was obtained from the personnel register of the millo but because of shortage of information the cases could only be classified as "exposed" or "nonexposed." At some places in the mill the concentrations of paper dust had previously been high, 10-30 3 $\mathrm{mg} / \mathrm{m}^{3}$. Employment at the paper mill was found to be associated with an increased risk of bronchial asthma and chronic obstructive pulmonary disease (odds ratio $=3.8, \mathrm{p}<0.05$ ).

Exposure to paper dust has been associated with impairment of pulmonary function. In a cross sectional study on workers exposed to soft paper dust Ericsson et al found significantly decreased FEV 1 and FVC among the most heavily exposed workers which could indicate both restrictive or obstructive pulmonary diseases. ' In the studies by Ferris et al $^{2}$ and Deprez et al $^{3}$ there were indications of an increased morbidity of asthma and chronic obstructive pulmonary disease (COPD) among paper and pulp mill workers. Järvholm et al have found an increased risk of mesothelioma among Swedish paper mill workers, ${ }^{4}$ and with this background it was decided to study further both the mortality from asthma and COPD and from respiratory cancer among paper mill workers.

For this purpose a case-referent study was undertaken in the parishes surrounding the mill where the previous investigation by Ericsson et al had been made.' This region is suitable for a case-referent study because the paper mill is the dominant industry in the area and the region has a convenient number of inhabitants, about 10000 .

\section{Subjects and methods}

SOURCE OF SUBJECTS

Subjects for the study, cases and referents, were obtained from the local registers of deaths and burials in three parishes surrounding the paper mill. The study

Accepted 29 February 1988 was restricted to men aged 40-75 who had died between 1965 and 1984. Men below the age of 40 wereo excluded because there were presumed to be few cases and the exposure times were likely to be short. Because, among older men the reliability of the causes of deatho stated on the death certificates are not as good as among younger categories we excluded men over 75 . $\overrightarrow{\overrightarrow{0}}$

Based on the information from the registers of 3 deaths and burials, a classification of causes of death was made according to the International Classification? of Disease (ICD 8, 1967). ${ }^{5}$ Cases included in the study were men who had died of COPD (ICD 490-92), 3 asthma (ICD 493), and respiratory cancers includingo mesothelioma (ICD 162-63). The referents, six for. each case, were randomly selected without individua $B$ matching from the total population of men with non malignant, non-respiratory diseases.

Thirty eight individuals were classified as cases and from the 281 available reference subjects 228 were. selected.

The diagnosis of the cases was checked agains $\tilde{\rho}^{\circ}$ hospital files or the Swedish Cancer Registry. Infor N mation was obtained for 33 cases $(87 \%)$. Of the five cases lacking information, three died of asthma opo COPD and two of lung cancer. As a result of the checking, five cases were excluded, four because of erroneous diagnoses on the death certificates (table 1) $\stackrel{\rho}{?}$ The fifth case was originally falsely selected because the birth date had been misread.

After these exclusions the study comprised 261 men 33 cases and 228 referents. Twelve cases died of asthmap 
Table 1 Diagnoses of excluded cases

\begin{tabular}{lll}
\hline & $\begin{array}{l}\text { Diagnosis in } \\
\text { registers of deaths } \\
\text { and burials }\end{array}$ & $\begin{array}{l}\text { Diagnosis in } \\
\text { hospital files }\end{array}$ \\
\hline Case 1 & Pleural tumour & $\begin{array}{l}\text { Pleural metastases from } \\
\text { fibrosarcoma } \\
\text { Wegener's } \\
\text { granulomatosis } \\
\text { Renal cancer with } \\
\text { pulmonary metastasis } \\
\text { Cholangitis with } \\
\text { empyaema }\end{array}$ \\
\hline Case 3 & Pulmonary bleeding \\
\hline
\end{tabular}

or COPD, 17 of lung cancer, and four of mesothelioma.

The 228 referents had many different diagnoses. To validate the analysis further it was decided to use more than one reference group. Therefore, a second reference group was selected from our original referents comprising all men with acute myocardial infarction (AMI). As a third reference group all men with cerebrovascular diseases (CVD) or AMI, or both, were selected. This gave 97 men with AMI and 124 men with CVD/AMI. The advantages of CVD and AMI are that they are common and well delineated and there is no known association with the exposures we were studying.

\section{ASSESSMENT OF EXPOSURES}

In the mill the production of soft paper began in 1942. Soft paper is used in the production of toilet paper, paper towels, and napkins. Compared with the production of "ordinary" paper the workers in a soft paper mill are more exposed to paper dust.

In the mill both stationary and personal sampling of total dust have been performed since 1976. Workers at the paper machines were intermittently exposed to about $20-40 \mathrm{mg} / \mathrm{m}^{3}$ and workers in the converting departments where the soft paper is processed to other products were constantly exposed to $5-20 \mathrm{mg} / \mathrm{m}^{3}$. More details about exposure in the mill are described by Ericsson et al.'

The intention was to classify all the subjects into different exposure categories with regard to paper dust based on their occupation in the mill, but as the personnel registers were incomplete with regard to occupational titles and periods of employment it was only possible to classify the men into "exposed" or "not exposed" categories. Thus exposed implies that the man was employed in the paper mill whereas not exposed implies that the man was not found in the personnel files. The information from the personnel files was supplemented with information from two old employees (employed more than $\mathbf{4 0}$ years each) who were unaware of the causes of death of the men. From their statements four more men, three referents and one case, were classified as exposed.

\section{STATISTICAL METHODS}

Statistical analysis of the data was based on MantelHaenszel procedures ${ }^{6}$ and the principles outlined by Axelson ${ }^{7}$; confidence intervals were calculated according to Miettinen. ${ }^{8}$ The fourfold table with asthma and COPD was also analysed with Fisher's exact test.

\section{Results}

\section{ASTHMA AND COPD}

Six of the 12 cases with asthma or COPD were exposed, which implies a significantly increased risk (odds ratio 3.8, p < 0.05) (table 2); the crude odds ratio, SMR, and the Mantel-Haenszel odds ratio were almost equal, 3.9 and 3.8 respectively. Hence, there is little or no negative confounding by age. The MantelHaenszel procedure is probably somewhat suboptimal with regard to the small numbers affected in the different strata, but when the unstratified material was analysed with Fisher's exact test the difference was still significant $(p<0.05)$.

Among the exposed were four cases with bronchial asthma and two with COPD. Among the unexposed were three cases with bronchial asthma and three with COPD. Hospital files were obtained for nine of the cases, four exposed and five unexposed. The exposed cases are presented in greater detail in table 3.

\section{RESPIRATORY CANCER}

There was no significantly increased risk for res-

Table 2 Distribution of cases with COPD and asthma (ICD 490-93) and referents by exposure

\begin{tabular}{lcc}
\hline Age group & Unexposed & Exposed \\
\hline 40-49: & 0 & 1 \\
Case & 10 & 3 \\
Referent & 1 & 0 \\
50-59: & 33 & 5 \\
Case & 2 & 3 \\
Referent & 66 & 23 \\
60-69: & 3 & 2 \\
Case & 72 & 16 \\
Referent & & \\
70-75: & 6 & 6 \\
Case & 181 & 47 \\
Referent & $(1.0)$ & 3.9 \\
Total: & $(1.0)$ & 3.9 \\
Case & $(1.0)$ & $3 \cdot 5$ \\
Referent & & \\
Crude odds ratio & $(1.0)$ & $3 \cdot 8$ \\
SMR & & $1 \cdot 2-12 \cdot 0$ \\
SRR & & \\
Mantel-Haenszel odds & & \\
ratio: & & \\
Point estimate & $95 \%$ Confidence interval & \\
\hline
\end{tabular}


Table 3 Exposed cases with asthma or COPD

\begin{tabular}{llllll}
\hline Case & Diagnosis & $\begin{array}{l}\text { Age at } \\
\text { disease } \\
\text { onset }\end{array}$ & $\begin{array}{l}\text { Age from } \\
\text { beginning } \\
\text { to end of } \\
\text { employment }\end{array}$ & $\begin{array}{l}\text { Age at } \\
\text { death }\end{array}$ & $\begin{array}{l}\text { Smoking } \\
\text { habits }\end{array}$ \\
\hline A $^{*}$ & Asthma & 44 & $39-54$ & 60 & $?$ \\
B $^{*}$ & Asthma & $?$ & $50-?$ & 61 & $?$ \\
C $^{*}$ & Asthma & 46 & $36-62$ & 62 & $?$ \\
D $^{*}$ & COPD & 66 & $44-68$ & 72 & Ex-smoker \\
E & Asthma? & $?$ & $24-43$ & 43 & $?$ \\
F & COPD? & $?$ & $?-65$ & 75 & $?$ \\
\hline
\end{tabular}

*Hospital files were available.

Table 4 Distribution of cases with respiratory cancers (ICD 162-63) and referents by exposure

\begin{tabular}{|c|c|c|}
\hline Age group & Unexposed & Exposed \\
\hline $\begin{array}{l}\text { 40-49: } \\
\text { Case } \\
\text { Referent } \\
\text { 50-59: }\end{array}$ & $\begin{array}{r}0 \\
10\end{array}$ & $\begin{array}{l}1 \\
3\end{array}$ \\
\hline $\begin{array}{l}\text { Case } \\
\text { Referent }\end{array}$ & $\begin{array}{r}4 \\
33\end{array}$ & $\begin{array}{l}1 \\
5\end{array}$ \\
\hline $\begin{array}{l}\text { 60-69: } \\
\text { Case } \\
\text { Referent } \\
\text { 70-75: }\end{array}$ & $\begin{array}{r}5 \\
66\end{array}$ & $\begin{array}{r}4 \\
23\end{array}$ \\
\hline $\begin{array}{l}\text { Case } \\
\text { Referent }\end{array}$ & $\begin{array}{r}6 \\
72\end{array}$ & $\begin{array}{r}0 \\
16\end{array}$ \\
\hline $\begin{array}{l}\text { Total: } \\
\text { Case } \\
\text { Referent }\end{array}$ & $\begin{array}{r}15 \\
181\end{array}$ & $\begin{array}{r}6 \\
47\end{array}$ \\
\hline $\begin{array}{l}\text { Crude odds ratio } \\
\text { SMR } \\
\text { SRR } \\
\text { Mantel-Haenszel odds ratio: }\end{array}$ & $(1 \cdot 0)$ & $\begin{array}{l}1.5 \\
1.6 \\
1.4\end{array}$ \\
\hline $\begin{array}{l}\text { Point estimate } \\
95 \% \text { Confidence interval }\end{array}$ & $(1 \cdot 0)$ & $\begin{array}{l}1 \cdot 6 \\
0 \cdot 7-3 \cdot 2\end{array}$ \\
\hline
\end{tabular}

Table 5 Odds ratios, SMR, and SRR among 12 cases with asthma or COPD and 97 referents with AMI and 124 referents with $A M I / C V D$

\begin{tabular}{lll}
\hline & \multicolumn{2}{l}{ Referents } \\
\cline { 2 - 3 } & $A M I$ & $A M I / C V D$ \\
\hline Crude odds ratio & $4 \cdot 1$ & $4 \cdot 3$ \\
Point estimate & $4 \cdot 0$ & $4 \cdot 4$ \\
95\% Confidence interval & $1 \cdot 2-12 \cdot 2$ & $2 \cdot 7-7 \cdot 1$ \\
SMR & $4 \cdot 0$ & $4 \cdot 3$ \\
SRR & $4 \cdot 4$ & $4 \cdot 5$ \\
\hline
\end{tabular}

piratory cancer among the exposed men (table 4). Four mesotheliomas were found among the cases; three were unexposed.

\section{ALTERNATIVE REFERENTS}

When referents with AMI were used the odds ratios for all cases and the cases with asthma or COPD were almost the same as the earlier calculations based on 228 men (table 5). When men with AMI or CVD, or both, are used together as a reference entity the odd $\stackrel{\mathbb{P}}{.}$ ratios were higher; the crude odds ratio was for the cases with asthma or COPD-4, 3, with Mantel Haenszel the point estimate was $\mathbf{4 \cdot 4}$.

\section{Discussion}

The present study suggests an excess mortality fromo asthma and COPD among workers in a soft paper? mill. There are, however, possible sources of bias in the study.

The diagnoses of the cases and referents obtained from the parish registers may be incomplete. These registers are based on the diagnosis from the death 3 certificates. In the present study the causes of deathis stated for the cases were compared with informationis from medical files and from the Swedish Cancer Registry. In accordance with that information fourv cases were excluded as having erroneous causes of? death.

In the present study asthma and COPD were analysed together although they are probably separate diseases. The reason is that asthma and COPD are often difficult to separate with information obtainedo from death certificates and hospital files that are oftenco incomplete.

Selection bias is not relevant because the subjects were selected with no knowledge of their earlier exposure status. In the selection of referents those whon had died from malignant diseases were excludeco to avoid a possible confounding effect of asbestos. $\frac{2}{\Rightarrow}$ Järvholm et al have described an excess of mesothe-⿳⺈ lioma among mainly maintenance personnel in Swedish paper mills. ${ }^{4}$

The selection of referents is important to the results, as is shown by the analyses with alternative referents. When AMI is used as a reference entity the result is 3 about the same but when CVD is also included amongo the referents the odds ratios increased.

It is unlikely that there was an observation bias ino the exposure classifications because they were made with no knowledge of the diagnosis of the subjects. 음 In addition, the estimation of exposure is based $>$ on presence in the personnel register, which is not? influenced by recall bias.

Another possible confounding factor is smoking $\%$ The smoking habits of the cases and referents cannot 0 be ascertained. Instead the actual smoking habits wereస్ట studied in a random sample of 400 men aged 20-75 ino the parishes around the paper mill. In a mailed questionnaire they were asked about their smoking habits and if they were working or had worked in the paper mill. The results are presented in table 6 . The response rate, about $80 \%$, was acceptable and the results indicate that smokers are equally prevalent in both groups. Ex-smokers are more prevalent among 
Pulmonary disease among workers in a soft paper mill

Table 6 Smoking habits among a random sample of 400 men from the parishes surrounding the paper mill

\begin{tabular}{llll}
\hline $\begin{array}{l}\text { History of } \\
\text { employment } \\
\text { in the paper mill }\end{array}$ & \multicolumn{2}{l}{ Smoking habits } & \\
\cline { 2 - 4 } & Non-smokers & Ex-smokers & Smokers \\
\hline Yes $(\mathrm{n}=81)$ & $28 \%$ & $45 \%$ & $27 \%$ \\
No $(\mathrm{n}=243)$ & $40 \%$ & $34 \%$ & $26 \%$ \\
\hline
\end{tabular}

the paper mill workers, however, indicating that the paper mill workers have smoked somewhat more often than other people in the region in the past. The confounding effect of this small difference in smoking habits is probably weak. Odds ratios exceeding three can scarcely be explained by different smoking habits. ${ }^{9}$

The increased mortality from asthma and COPD among paper mill workers is supported by other studies. Ferris et al have, in a study from the United States in 1963, observed a proportionate mortality of $15 \%$ from asthma and COPD and respiratory insufficiency among paper and pulp mill workers. ${ }^{2}$ This is not discussed further in the paper but, compared with Sweden, it seems a rather high death rate. In a study from Finland Niemelä et al found a significantly increased prevalence of confirmed diagnosis of bronchial asthma among debarkers in a paper mill. ${ }^{10}$ Another study from the United States by Deprez et al showed that hospital admission rates for COPD and asthma were positively correlated with the proportion of the workforce of a town employed at a pulp or paper mill. ${ }^{3}$ It is not clear from that study, however, whether they have studied paper mill workers, pulp mill workers, or both.

By contrast, Chan-Yeung et al found no signs of increased prevalence of respiratory diseases and abnormal lung function among workers in a paper mill where the dust concentrations were low, beneath $5 \mathrm{mg} / \mathrm{m}^{11}$.

In conclusion despite the presence of smoking as a potential confounding factor, the present study provides evidence of a possible association between employment in a Swedish soft paper mill and increased mortality in asthma and COPD.

We thank Mr Sixten Ivarsson, Dr Mats Jönsson, and Mrs Kerstin Johanson for their help in data collection.

\section{References}

1 Ericsson J, Järvholm B, Norin F. Respiratory symptoms and function in workers exposed to soft paper tissue dust. Int Arch Environ Health 1988;60:341-5.

2 Ferris BG, Puleo S, Chen HY. Mortality and morbidity in a pulp and a paper mill in the United States: a ten-year follow-up. $B r J$ Ind Med 1979;36:127-34.

3 Deprez PP, Oliver C, Halteman W. Variations in respiratory disease morbidity among pulp and paper mill town residents. $J$ Occup Med 1986;28:486-91.

4 Järvholm B, Malker H, Malker B, Ericsson J, Sällsten G. Pleural mesotheliomas and asbestos exposure in the pulp and paper industries. Am J Ind Med 1988;13:561-7.

5 National Central Bureau of Statistics. Classification of causes of death in Swedish statistics. Stockholm: NCBS, 1973.

6 Mantel N, Haenszel W. Statistical aspects of the analysis of data from retrospective studies of disease. JNCI 1959;23:719-48.

7 Axelson O. The case-referent (case-control) study in occupational health epidemiology. Scand J Work Environ Health 1979;5: 91-9.

8 Miettinen OS. Estimability and estimation in case-referent studies. Am J Epidemiol 1979;103:226-35.

9 Axelson O. Aspects on confounding in occupational health epidemiology. Scand J.Work Environ Health 1978;4:85-9.

10 Niemelä SI, Väätänen P, Mentu J, et al. Microbial incidence in upper respiratory tracts of workers in the paper industry. Appl Environ Microbiol 1985;50:163-8.

11 Chan-Yeung M, Wong R, MacLean L, et al. Respiratory survey of workers in a pulp and paper mill in Powell River, British Columbia. Am Rev Respir Dis 1980;122:249-57. 